\title{
Jelena Ćeriman
}

Institut za filozofiju i društvenu teoriju, Univerzitet u Beogradu jelena.ceriman@instifdt.bg.ac.rs

\section{Modeli rodne socijalizacije dečaka u porodicama u savremenoj Srbiji"}

Apstrakt: Rad se fokusira na proces porodične rodne socijalizacije dečaka u savremenom društveno-kulturnom kontekstu Srbije, praćeno preko vaspitnih praksi roditelja. Analiza je bazirana na empirijskom materijalu prikupljenom 2012. na uzorku od 24 porodice sa decom uzrasta 2-12 godina. Na osnovu stalne uporedne analize (metoda građenja teorije) vaspitnih praksi roditelja - očeva i majki, koje obuhvataju njihove stavove i postupke, u tekstu se prikazuju i interpretiraju modeli rodne socijalizacije dečaka i pozicioniraju na kontinuumu od izrazito tradicionalnih do izrazito modernih vaspitnih praksi roditelja. Iako su tradicionalne vaspitne prakse najzastupljenije u uzorku ovog istraživanja, analizom su izdvojena tri modela rodne socijalizacije dečaka: tradicionalni, prelazni i participativni. Dva potonja modela predstavljaju iskorak u pravcu individualizacije roditeljstva, a razvijaju se prevashodno pod uticajem dinamike partnerskih odnosa, odnosno usled prevazilaženja ,žrtujućeg majčinstva“ kod jednog dela žena iz uzorka u pravcu ,žrtvovanja“ oca, tj. odricanja od jednog dela privilegija koje je uživao pre preuzimanja zaduženja brige i staranja o deci.

Ključne reči: rodna socijalizacija, vaspitne prakse, porodica, roditeljstvo, Srbija

Istraživanja porodičnih praksi i odnosa na nivou društva Srbije beleže promene u pravcu (pre)komponovanja domaćinstava i porodica budući da jednim delom prate trend pluralizacije partnerskih i porodičnih formi karakterističnih za globalna kretanja društava koja, prema teorijskim pretpostavkama, spadaju u zemlje Druge demografske tranzicije (Milić 2001, 122-128; Bek 2001, 2003; Bobić 2003, 65-91; 2013; Stanojević 2018). S druge strane, ovi procesi se nalaze u koliziji s određenim elementima predmodernih porodičnih praksi koje i dalje opstaju u društvu Srbije (Milić 2010b, 235-256). Razloge tome prevashodno možemo naći u društvenom kontekstu porodičnog života u Srbi-

* Ovaj rad predstavlja izvod iz odbranjene doktorske disertacije autorke. Disertacija je odbranjena 27.09.2019. godine na Filozofskom fakultetu Univerziteta u Beogradu. 
ji na koji najveći uticaj ima kompleksna društvena transformacija s kraja XX veka. Krizne devedesete zaustavile su proces modernizacije i vratile porodice na ranije strategije i prakse održanja (Milić et al. 2010). Značajno su i produbljene razlike u pojedinim klasno diferenciranim varijetetima porodica u Srbiji (Tomanović 2010, 177-194). Utvrđeno je da se „razlike između roditelja koji pripadaju različitim društvenim slojevima pokazuju najpre u potenciranju 'žrtvujućeg' naspram 'egalitarnog' modela roditeljstva, što se reflektuje i u prihvatanju, odnosno odbacivanju tradicionalističkih stavova o roditeljskim ulogama“" (Tomanović 2010, 193-194). U datom istraživanju, kao i u studiji iz 1993/4. godine (videti Tomanović-Mihajlović 1997) intelektualna radoznalost se pojavljuje kao slojno diskriminatorna. Naime, Tomanović-Mihajlović je utvrdila da radnici najviše vrednuju konformističke osobine poput poštenja, lepog ponašanja i poslušnosti, a najmanje intelektualnu radoznalost. Roditelji pripadnici srednje klase imaju mnogo više razumevanja i odobravanja za individualni razvoj deteta, dok su roditelji pripadnici radničke klase represivniji, zanemaruju potrebe deteta i ne podstiču razvoj njegove samostalnosti (Tomanović-Mihajlović 1997, 100). Upotreba fizičkog kažnjavanja kao disciplinskog metoda najzastupljenija je u radničkoj klasi, dok roditelji koji pripadaju srednjoj klasi češće koriste ubeđivanje i psihološke tehnike vaspitanja (videti u Tomanović-Mihajlović 1997, 109-110). S druge strane, savremena istraživanja u Velikoj Britaniji dovode u pitanje ovako shematizovan prikaz klasno-slojne diversifikacije vaspitnih stilova (NFPI 2001). Međutim, kod ove činjenice mora se imati u vidu društveni kontekst u kojem se istražuje data relacija. Kontekst savremenog britanskog društva, na primer, podrazumeva smanjenje strukturalnih razlika u vaspitanju dece usled značajnog uticaja medija na proces socijalizacije i, još važnije, usled procesa individualizacije roditeljstva. Nasuprot tome, istraživanja roditeljstva u Srbiji pokazuju da se ne radi o homogenom fenomenu već da postoji izražena slojna različitost koja se iskazuje „u različitim kvantitetima i kvalitetima ekonomskog, kulturnog i socijalnog kapitala koji porodice poseduju, i koji preko habitusa opredeljuju norme, aspiracije i praksu roditeljstva“" (Tomanović 2010, 181). Druga novija empirijska istraživanja porodičnog života pokazuju da bi nastavak procesa modernizacije u porodicama u Srbiji mogao uticati na uniformizaciju potreba i životnih stilova pojedinaca i zaustaviti dalje klasno profilisanje porodica (Milić 2010a, 29-30). Pretpostavka iz istraživanja je da će pravci daljeg razvoja roditeljstva (majčinstva i očinstva), odnosno individualizacija roditeljstva, a sa njom i oblikovanje procesa rodne socijalizacije dečaka, zavisiti od šireg konteksta odnosa koji se formiraju u javnoj sferi, kao i od porodične i partnerske dinamike na mikro nivou. Fleksibilniji odnosi karakteristični za kasnu modernu (Bek 2001, 2003; Bobić 2003) mogu voditi u ravnopravniju raspodelu moći, obaveza i odgovornosti u okviru domaćinstva između žena i muškaraca. Ukoliko pojedinci unutar porodične grupe neguju viši stepen fleksibilnosti, koja 
se gradi u dugom vremenskom periodu, ali i viši stepen kohezivnosti i otvorene komunikacije (Olson 1999), lakše će se nositi sa sopstvenim obavezama i organizovati oko brige i nege dece, a i konstruktivnije će reagovati na promene koje zahtevaju prilagođavanje.

Pored socio-ekonomske pripadnosti roditelja i rod i uzrast deteta takođe određuju vaspitne prakse roditelja. Novije istraživanje sprovedeno u okruženju (Babović et al. 2016) pokazalo je da roditelji kod devojčica „Značajno češće podstiču osjećajnost, osjetljivost i nježnost nego kod dječaka, a upravo ove osobine se smatraju vrlinama za žene u tradicionalnim i patrijarhalnim okvirima, gdje se očekuje njena primarna usmjerenost na porodicu" (Babović et al. 2016, 24-25). „Muška djeca se više podstiču na razvijanje vještina koje će u odraslom dobu omogućiti da se 'snađu' na tržištu rada i uopšte, u javnoj sferi, dok se ženska djeca više podstiču na razvijanje 'simboličkog', ali ne i stvarnog kapitala, odnosno umjetničkim vještinama, osjećaju za lijepo, koje više koristi u privatnom životu nego na tržištu rada“" (Babović et al. 2016, 25). Ovo važi za uzrast od rođenja do 14 godine deteta i podstiče se kroz različite aktivnosti, igru, odnose i zaduženja u domaćinstvu itd. Na uzrastu dece od pet do 14 godina: „Dječaci se više uključuju u ekonomske aktivnosti, one koje su povezane sa tržišnim radom ( rad na gazdinstvu, u porodičnom poslu), dok se djevojčice više uključuju u kućni rad i tako socijalizuju za ulogu nosilaca brige o domaćinstvu i porodici u odraslom dobu" (Babović et al. 2016, 26, istaknuto u originalu). Različite norme za devojčice/žene i dečake/muškarce u ovim istraživanjima moguće je opisati i kao „privilegovani muški kodeks“ (Mladenović 1976). Datim kodeksom se potvrđuju patrijarhalne odrednice o muškarcima koji nastavljaju tradiciju kontrolišući doslednu primenu principa koji stoje u njenoj osnovi, dok su žene odgovorne za dosledno prenošenje sadržaja tradicije na nove generacije.

Kategorija heteronormativne porodice sa jasno određenim rodnim ulogama muškarca i žene podržana je od strane javnih sektora društvenog života i građanske familističke ideologije porodice i kao takva je postavljena za normirajući obrazac za sve druge tipove porodičnih formi (Milić 2010b, 235-256; Tomanović i Stanojević 2015). Uz to, opadanje rasta stanovništva ohrabruje diskusije i o krizi porodice i krizi porodičnih vrednosti. Debate o krizi porodice, krizi porodičnih vrednosti i krizi maskuliniteta (Šmale 2011) jednim delom sadrže novi talas učvršćivanja upravo patrijarhalne kulture, odnosno održavanja stroge distance između različitih, suprotnih, pa i suprotstavljenih u ovom diskursu, polno/rodnih kategorija. Namera ovog rada je da istraži roditeljske prakse koje omogućavaju reprodukciju stereotipnih rodnih modela, kao i roditeljske prakse koje otvaraju prostore za potencijalno odstupanje od stereotipa u procesu rodne socijalizacije dečaka i modifikaciju falogocentrične društvene strukture koja preko patrijarhalne logike opterećuje i muškarce i žene u savremenoj Srbiji. 
U procesu rodne socijalizacije u porodici, društveno-istorijske i kulturno konstruisane norme prenose se i transformišu međugeneracijski, formirajući osnovne predstave o rodnosti i konstruišući u povratnoj sprezi polja društvene realnosti. Maskulinitet i feminitet se interiorizuju kroz normative kojima se želi regulisati svakodnevno funkcionisanje u falogocentričnom, odnosno patrijarhalnom sistemu koji žene i muškarce, te njihove rodne performanse vidi kao prirodne, statične i nepromenljive (Bordo 2003, 311-331). Ako se rod razumeva kao neka vrsta činjenja, odnosno delanje koje se izvodi delom i bez znanja i htenja konkretne osobe, on zbog toga nije i automatski. Naprotiv, on je praksa unutar jedne scene ograničenja (Butler 2005). Štaviše, niko sam ne čini vlastiti rod. Rod se čini sa drugima ili za drugog, čak i kada je drugi imaginaran. Uslovi koji sačinjavaju nečiji rod od početka su van tog nekog (Butler 2005). Takav vid socijalizacije posebno je artikulisan unutar porodice kao jednog vida autoriteta. Naše shvatanje sveta zasnovano je na društvenim i kulturnim konstruktima koji nastaju u međusobnim odnosima s drugim ljudima (Ber 2001). Ovi konstrukti su promenljivi i relativni, a njihovi konstruktori su i sami učesnici u interakciji. Socijalna realnost stoga može biti istovremeno i objektivna i subjektivna (Berger and Luckmann 1991). „Procesi eksternalizacije, objektivizacije i internalizacije doprinose da se društveni fenomeni doživljavaju kao prethodno dati i fiksirani“ (Radulović 2009, 87), dok su istovremeno podložni promeni i kreirani u međusobnim interakcijama različitih ljudi ${ }^{1}$. U skladu sa pristupom prakse (Ortner 1974), socijalizacija u ovom radu se razume kao praksa socijalne reprodukcije koja posreduje između struktura i pojedinca, ali koja je istovremeno i proizvod njihovog međusobnog delovanja (koncept dvostruke strukturacije, videti Giddens 1984). U tom smislu, pojedinci nisu pasivni objekti socijalne reprodukcije, već čine i subjekte prakse. Proces (među)generacijskog kontinuiteta (Tomanović 1993, 303-315) odvija se preko prenošenja i usvajanja određenog kulturnog kodeksa, međutim prakse u porodici podložne su i mogućim transformacijama ukoliko u njima postoji preispitivanje kulturno i društveno-istorijski uslovljenih normi i akcija u pravcu njihove promene, odnosno transformacije struktura. Umesto da se govori o rodu kao nekakvoj zatečenosti, Konel (Connell 1995) ističe upravo „društvenu proizvodnju“ roda. Konel maskulinitete i femininosti shvata kao promenljiv skup značenja koje konstruišemo u odnosu sa samima sobom, sa drugima i sa svetom (Connell 2000, 23-26). Konstrukt maskuliniteta,

${ }^{1}$ U ovom radu kombinujem socijalno konstrukcionističku paradigmu sa teorijama rodne socijalizacije. Iako su teorije socijalnog konstrukcionizma kritikovale teoriju rodne socijalizacije, ove teorije se ipak mogu posmatrati pre komplementarno, nego konkurentski (Stanojević 2015). „Za razliku od teorije socijalizacije koja roditeljske modele smatra primarno zavisnim od dispozicija ličnosti i naučenih modela ponašanja, socijalni konstrukcionizam ih tumači u odnosu na (društvene) okolnosti zbog kojih se ovi modeli stvaraju“ (Stanojević 2015, 315). 
smatra Konel, iskazan je u rodnom identitetu koji je u saglasnosti sa zahtevima dominantnih rodnih normi u određenoj socijalnoj grupi ili društvu, a realizuje se posredstvom različitih interakcija. Kimel (Kimmel 2009) ističe da se u okviru jednog društva, u okviru različitih kulturnih sfera, može pronaći više različitih tipova maskuliniteta. U multikulturnim društvima, na primer, dominantni, odnosno hegemoni maskulinitet održava predstave o muškoj rodnoj ulozi koje deli većinski deo društva. Ipak, hegemoni maskulinitet ne javlja se kao najčešća forma maskuliniteta već predstavlja ideal kako bi trebalo da izgleda i da se vlada pravi muškarac, a ovakav stav nameće grupacija (ili grupacije) koja u datom društvu poseduje najveću moć. Maskulinitet se, dakle, pokazuje i javlja kao rezultat aktivnog (re)konstruisanja u konkretnim istorijskim uslovima, te se može govoriti o postojanju različitih tipova maskuliniteta, to jest o odgovarajućim normama, pravilima ponašanja i moralnim vrednostima koja se vezuju za pravog muškarca.

U skladu sa svim navedenim aspektima, proces rodne socijalizacije dečaka u ovom radu posmatra se kao relacioni fenomen čija se multidimenzionalnost ogleda u složenoj mreži odnosa roditelja (očeva i majki), dece i drugih aktera u specifičnom društvenom kontekstu. Pod uticajem spleta navedenih odnosa oblikuje se proces porodične rodne socijalizacije dečaka, što se u ovom radu istražuje preko vaspitnih praksi roditelja, koje uključuju roditeljske postupke i stavove. Pojam socijalizacije ispitan je isključivo preko procesa transmisije, a ne i procesa internalizacije, pa su u istraživačkom fokusu roditelji majke i očevi i njihove vaspitne prakse. Definicija vaspitnih praksi razvijena je na osnovu koncepcije vaspitnih postupaka kod Biljane Bodroški Spariosu (2010), a koji su definisani preko pet dimenzija: nivoa zahteva koje roditelji postavljaju deci, stepena kontrole dece, načina kontrole ili stepena uvažavanja ličnosti deteta u postupku kontrole, emocionalnog odnosa prema detetu i doslednosti roditelja u vaspitanju deteta. $\mathrm{Na}$ osnovama ove definicije, vaspitne prakse su određene kao skup aktivnosti i odnosa u porodici putem kojih roditelji ostvaruju svoje vaspitne ciljeve, a ovi vaspitni ciljevi proizlaze iz vrednosti i vaspitnih stavova roditelja. Stavovi čine osnovu za formiranje i razvoj roditeljskih vaspitnih ciljeva u procesu rodne socijalizacije. Budući da stavovi, kao sastavni element vaspitnih praksi, imaju i dinamičko dejstvo, oni deluju kao podstrekači na određeno ponašanje. Prema tome, stav roditelja je ,usvojena struktura saznajno-afektivnog karaktera i težnja ka određenom, relativno nepromenljivom načinu ponašanja roditelja prema detetu (posebno majke i posebno oca)“(Ziemska 1973, prema Petrović-Piorkowska 1990, 57). $\mathrm{Za}$ istraživanje procesa rodne socijalizacije dečaka u ovom radu, naročito za uviđanje raskoraka između vaspitnih ciljeva i vaspitnih praksi roditelja, posebno je značajan koncept implicitnih pedagogija koji predstavlja „diskurziv- 
no neartikulisane sadržaje svesti koji se odnose na osnovne pojmove u vezi sa vaspitanjem“ (Tomanović-Mihajlović 1997, 100), a koji određuju roditeljske prakse u procesu rodne socijalizacije. To su ,prikriveni, neosvešćeni, nesvesni činioci koji utiču na ponašanje odraslih u odnosima s decom" (Graorac 2016, 125), a za koje se smatra da imaju veći uticaj od svesnih činilaca (Graorac 2016). To je posebno značajno za istraživanja roda budući da se normativi o rodu interiorizuju u najranijem dobu, pa se učešće u njihovoj kasnijoj reprodukciji teško identifikuje u svesti. Implicitne pedagogije sadrže predstave roditelja o detetu i poželjnom ishodu procesa rodne socijalizacije, odnosno poželjnim osobinama, ponašanjima, ličnosti deteta itd. (implicitne pedagogije subjekata ovog istraživanja ispitane su preko koncepata dobar dečak i dobra devojčica, pri čemu devojčice čine kontrolnu grupu), kao i predstave roditelja o sadržaju i ciljevima vaspitanja, roditeljstvu itd. (ovaj aspekt implicitnih pedagogija ispitan je preko koncepata dobra majka, dobar otac, odnosno pitanja o idealnom vaspitavanju sina i idealnom vaspitavanju ćerke).

Koncepte dobra majka, dobar otac, kao i dobar dečak i dobra devojčica u savremenoj Srbiji prevashodno određuje normativni okvir roditeljstva iskazan kroz familističku porodičnu ideologiju (za detaljno određenje navedenih koncepata u ovom istraživanju videti Ćeriman 2019a; 2019b). Familizam vidi ideal porodice u nuklearnoj zajednici koju čine bračni partneri sa decom, a primarna funkcija heteronormativne bračne zajednice, koja stoji u osnovi porodice, jeste briga o detetu čije su potrebe uvek ispred potreba roditelja (Tomanović 2017, 2-5). Koncept dobar otac uključuje u sebe osobine neophodne da se ispuni uloga hranioca i zaštitnika porodice, dok koncept dobra majka uključuje karakteristike neophodne za uspešno obavljanje uloge brižne starateljke. Majke atribut dobre majke nastoje da dostignu uspešnim vođenjem domaćinstva i vaspitavanjem dece (Tomanović-Mihajlović 1997; Tomanović 2017). Očevi atribut dobrog oca nastoje da dostignu preko uloge hranioca porodice, odnosno glavnog materijalnog pružaoca, te osobe koja porodičnu grupu brani od spoljašnjih simboličkih i realnih napada (Tomanović-Mihajlović 1997; Tomanović 2017). $\mathrm{Na}$ ovim osnovama definišu se i koncepti dobar dečak i dobra devojčica, koji bi trebalo da „uspešno zamene prethodnu generaciju” (Ćeriman 2019b, 404). Prateći prisustvo elemenata koji sačinjavaju navedene koncepte u stavovima roditelja utvrđeni su normativi koji stoje u osnovi vaspitnih praksi očeva i majki u ovom istraživanju, a kojima je određen i sadržaj procesa rodne socijalizacije, te stoga i raskorak između onoga što roditelji postavljaju kao cilj rodne socijalizacije dečaka i onoga što zaista čine u praksi.

U narednom poglavlju sledi detaljan prikaz metodološkog okvira, nakon čega će biti prikazani i interpretirani empirijski nalazi zaključno sa razmatranjima rezultata u poslednjem segmentu rada. 


\section{Metodologija}

Analiza u ovom radu izvedena je na osnovu empirijskog materijala koji čini 48 polustrukturisanih dubinskih intervjua, sprovedenih tokom 2012. godine sa 24 porodice (bračni parovi sa decom) u Srbiji. Osnovni materijal koji predstavlja empirijsku bazu ovog rada čine narativi očeva i majki o njihovom iskustvu roditeljstva. U uzorak su ušla naselja iz četiri statistička regiona Srbije: Beograd, Vojvodina, Šumadija i zapadna Srbija, Južna i istočna Srbija. Korišćenjem metoda slučajnog broja na listi opština, u okviru ovih regiona odabrano je šest opština: Beograd (obavljeno je 12 intervjua), Zrenjanin (6 intervjua), Novi Sad (8 intervjua), Čačak (6 intervjua), Vranje (8 intervjua) i Novi Pazar (8 intervjua). Birane su porodice iz urbanih i ruralnih područja navedenih opština kako bi se pratila veza između tipa naselja i vaspitnih praksi roditelja. Odabrane porodice sačinjavaju bračni parovi sa minimalno dvoje dece različitog pola da bi se pratile razlike u vaspitnim praksama roditelja prema sinovima i ćerkama, pri čemu ćerke predstavljaju kontrolnu grupu u ovom istraživanju. U polovini ispitanih porodica ćerka je najstarije dete, a u drugoj polovini porodica - sin. Ovakvo, kvotno, uzorkovanje omogućilo je da se ispitaju stavovi o različitom vrednovanju muške i ženske dece u datim porodicama, kao i da se izvrše poređenja vaspitnih praksi roditelja u odnosu na redosled rođenja sina (prvorođen ili drugorođen). Raspon uzrasta dece $u$ odabranim porodicama je od 2 do 12 godina kako bi se ispitao proces rodne socijalizacije dece koja se nalaze u predadolescentnom periodu. Donja granica starosti dece (2 godine) postavljena je kako bi se uzorkom obuhvatila deca sa kojima su roditelji mogli uspostaviti dublju dvosmernu interakciju. Još jedan unapred zadati kriterijum izbora uzorka podrazumevao je homogenost odabranih porodica u pogledu subjektivno procenjenog socio-ekonomskog položaja i prosečnih mesečnih primanja na nivou domaćinstva kako bi se ispitale vaspitne prakse roditelja u porodicama koje bi se, prema ovim kriterijumima, mogle odrediti kao prosečno domaćinstvo u Srbiji. Tokom procesa regrutacije, prema unapred pripremljenim pitanjima o primanjima, zaposlenosti i opremljenosti domaćinstva, iz uzorka su isključene porodice koje su u društvenoj hijerarhiji bile ispod i iznad republičkog proseka za istraživani period. U uzorak su ušle porodice jednakog subjektivno procenjenog socio-ekonomskog statusa i bliskih materijalnih primanja, odnosno porodice u kojima su zaposleni članovi domaćinstva imali ukupna mesečna primanja u rasponu od 35.000-55.000 dinara ${ }^{2}$ i u kojima su sagovornici i sagovornice izrazili saglasnost sa sledećim izjavama:

2 Raspon je odabran prema podacima Republičkog zavoda za statistiku Republike Srbije o prosečnim neto zaradama u godini izvođenja istraživanja. Podaci su dostupni na linku: URL: $<$ http://www.cekos.rs/statistika/zarade-prose\%C4\%8Dne-neto-zarade-u-srbiji/2012> (pristupljeno 15.11.2020.)

Етноантрополочки проблеми, н.с. год. 16 св. 1 (2021) 
1. Domaćinstvo u kojem živimo ima sve potrebne komunalne priključke (struja, voda, telefon - fiksni ili mobilni).

2. Naša porodica je prosečna, u njoj jedno ili oba roditelja zarađuju i brinu o deci.

3. Našoj porodici možemo da priuštimo uglavnom ono što mogu prosečni pripadnici srednje klase u našem okruženju.

i neslaganje sa sledećim izjavama:

1. Trebalo bi da primamo finansijsku pomoć od države. Jedva sastavljamo kraj s krajem.

2. Suprug/Supruga ili ja imamo zaradu koja je visoko iznad proseka za mesto u kojem živimo.

U uzorak je uključeno osam bračnih parova koji sa svojom decom žive u proširenoj porodici kako bi se testirali zaključci dobijeni analizom vaspitnih praksi roditelja koji žive u nuklearnoj porodici, a kojih je bilo ukupno 16. Iako je sasvim moguća primedba ovako postavljenom uzorku istraživanja kao isključujućem prema jednom delu stanovništva Srbije jer su intervjui isključili jednoroditeljske porodice, vanbračne zajednice i marginalizovane pripadnike i pripadnice stanovništva Srbije, namera ovog istraživanja bila je da se napravi uvid u prakse roditeljstva i stavove roditelja u porodicama čija je struktura postavljena kao normativ, te da se uoče moguće transformacije roditeljstva u heteronormativnim porodičnim formama. Korišćena tehnika za odabir uzorka je ,grudva snega”. Kako bi se izbeglo da u uzorak uđu porodice sličnih socijalnih biografija korišćena je široka mreža kontakata za regrutaciju potencijalnih sagovornika i sagovornica. Do sagovornika i sagovornica se dolazilo preko preporuka porodica sa kojima je već obavljen intervju, ali i preko ličnih kontakata istraživačkog tima čime se nastojalo dobiti na heterogenosti uzorka u pogledu obrazovnog nivoa, zanimanja i radnog statusa potencijalnih sagovornika i sagovornica. Tehnika grudve snega odabrana je kako bi se u okviru vremenskih i materijalnih ograničenja istraživanja na najoptimalniji način stiglo do potencijalnih sagovornika i sagovornica koji bi odgovarali postavljenim kriterijumima za ulazak u uzorak. Prilikom jedne posete porodici obavljani su intervjui sa ocem i majkom, istovremeno i u odvojenim prostorijama u domaćinstvu, kako bi se postigla situacija međusobnog neuticanja na odgovore. Sve intervjue sa očevima je obavio istraživač, dok je istraživačica obavila sve intervjue sa majkama kako bi se izbegla rodna pristrasnost (gender bias), tj. metodološka greška koja može nastati usled uticaja pola istraživača na odgovore sagovornika i sagovornica. Intervjui su snimani diktafonom uz saglasnost sagovornika i sagovornica i kasnije su transkribovani radi analize dobijenih podataka. Prosečno trajanje intervjua je bilo 1.5 čas. Svi sagovornici i sagovornice su bili raspoloženi da otvoreno razgovaraju na temu roditeljstva što bi se moglo tumačiti i njihovom ličnom upitanošću o različitim aspektima roditeljstva, a često i željom da sa istraživačkim timom podele vlastita pozitivna iskustva roditeljstva. 
Tabela 1. prikazuje pregled strukture uzorka, organizovanog prema polu, a za tri kategorije: najviše stečeno obrazovanje, zanimanje, tip naselja. U tabeli su dati realni brojevi, kako bi se izbeglo navođenje na pogrešan zaključak o veličini pojedinih delova uzorka jer je uzorak pravljen prema modelu teorijskog uzorkovanja, kojem cilj nije postizanje reprezentativnosti uzorka već obezbeđenje podataka $\mathrm{u}$ skladu s korišćenim analitičkim okvirom - metodom utemeljene teorije (Corbin i Strauss, 1990). Metoda je prvo dobila ime stalni uporedni metod (constant comparative method) da bi je kasnije nazvali grounded theory (metoda građenja teorije ili metod utemeljene teorije). Naziv upućuje na proces generisanja teorije iz podataka, tj. utemeljenje teorije u podacima prikupljenim u istraživanju. Prikupljanje podataka i analiza podataka obavljaju se istovremeno (analiza podataka počinje već nakon nekoliko obavljenih intervjua). Analizom se izdvajaju kategorije koje mogu usmeriti dalje prikupljanje podataka (Glaser and Strauss, 1967a; 1967b), odnosno svaka faza istraživanja usmerava tok naredne faze.

Tabela 1. Pregled uzorka N=48, Nž=24 i Nm=24

\begin{tabular}{|c|c|c|}
\hline & Žene & Muškarci \\
\hline \multicolumn{3}{|l|}{ Obrazovni nivo $^{3}$} \\
\hline Bez škole i nezavršena osnovna škola & 0 & \\
\hline Završena osnovna škola & 1 & 0 \\
\hline Zanat ili trogodišnja srednja škola & 4 & 6 \\
\hline Četvorogodišnja srednja škola/gimnazija & 15 & 13 \\
\hline Fakultet & 4 & 3 \\
\hline Specijalizacija, postdiplomske studije & 0 & 1 \\
\hline \multicolumn{3}{|l|}{ Zanimanje } \\
\hline NKV, PKV radnik & 0 & 1 \\
\hline KV, VKV radnik & 5 & 10 \\
\hline Službenik & 10 & 8 \\
\hline Stručnjak & 3 & 3 \\
\hline Nezaposleno lice & 6 & 2 \\
\hline \multicolumn{3}{|l|}{ Tip naselja } \\
\hline Grad & 13 & 13 \\
\hline Selo & 11 & 11 \\
\hline
\end{tabular}

U ovom istraživanju odabran je pristup koji se zasniva na jasno definisanim koracima u prikupljanju, beleženju, kodiranju i rekodiranju podataka, kao i na unapred postavljenim istraživačkim pitanjima, te analitički aparat $\mathrm{u}$ tom smislu odgovara Štrausijanskom pravcu razvoja rečene metode, odnosno tzv. paradigmatskom modelu koji su razvili Štraus i Korbin (Corbin i Strauss, 1990).

3 Jedan sagovornik nije želeo da pruži odgovor na ovo pitanje.

${ }^{4}$ Metod su razvili američki sociolozi Glaser i Štraus (Glaser and Strauss, 1967a). Vremenom su zauzeli različite pozicije u razvoju i primeni metode. Kroz njihov kasniji samostalni rad razvile su se dve struje u primeni metode utemeljene teorije (Boychuck i Morgan, 2004). Osnovna razlika 
$\mathrm{Za}$ analitički pristup odabrana je analiza narativa, jer omogućava da se na optimalan način dođe do dubinskog razumevanja značenja koje roditelji daju sopstvenim praksama u procesu rodne socijalizacije dečaka. Svi narativi su najpre analizirani kao studije slučaja, a zatim su pojedinačna iskustva međusobno upoređivana. Proces analize se odvijao na sledeći način:

- čitanje transkripata i beleški sa terena radi detaljnog upoznavanja sa prikupljenim podacima;

- početni korak u analizi predstavljalo je kodiranje prema temama, odnosno analiza je započeta identifikovanjem kategorija prema temama na koje se mogu izdeliti obavljeni intervjui (tzv. otvoreno kodiranje). Kodirane su što veće celine transkripta jednom kategorijom kojoj taj deo teksta odgovara svojom sadržinom, pošto je cilj istraživanja da se prepoznaju iskustva kroz koja roditelji prolaze i da se utvrde značenja koja im oni sami daju. Svi delovi teksta kodirani su sa više kodova, čime su se donekle zadržale veze iz narativa sagovornika i sagovornica. Stalno vraćanje na transkripte i njihovo ponovno čitanje omogućilo je detaljno upoznavanje sa narativima sagovornika i sagovornica, što je omogućilo da se izdvojeni citati mogu lakše povezivati sa celokupnim narativom sagovornika i sagovornica u kasnijem toku analize. Prilikom narednih čitanja transkripata uzimane su u obzir načinjene zabeleške o sadržaju i značenju delova transkripata nastojeći da se uvide veze između različitih kategorija koje se pojavljuju u materijalu.

- Zatim je sledila interpretacija kodiranih delova intervjua sa stanovišta istraživačkih pitanja i postavljenog teorijskog okvira u kontekstu pojedinačnih iskustava. Proces interpretacije započet je još tokom prethodnog koraka jer su tokom kodiranja transkripata beleženi komentari o pojedinačnim delovima iskustva. Tom prilikom su razmenjivana mišljenja sa kolegom istraživačem koji je obavljao intervjue sa očevima. Predmet analize u ovoj fazi činili su koncepti grupisani oko izdvojenih kategorija. Hipotetičke veze između kategorija i potkategorija dobijene u ovom (aksijalnom) kodiranju, dobijale su svoju potvrdu ili bi bile odbačene u procesu stalnog upoređivanja sa novim podacima. ${ }^{5} \mathrm{U}$ ovoj fazi ustanovljeni modeli rodne socijalizacije dečaka povezivani su sa obeležjima sagovornika i sagovornica i na taj način su tumačene razlike među njima. Izdvajani su i specifični slučajevi koji su tumačeni u odnosu na celokupni narativ sagovornika ili sagovornice.

- Selektivnim kodiranjem (trećim korakom u kodiranju) sprovedeno je povezivanje izdvojenih kategorija iz druge faze analize i to tako što su se kategorije pove-

između pristupa ogleda se u tome da li istraživač koristi unapred definisanu paradigmu kodiranja ili ulazi u istraživanje bez ideje o predmetu istraživanja (koliko je to moguće) imajući poverenja da će teorija sama iskrsnuti iz podataka u nekom trenutku (Boychuck i Morgan, 2004).

${ }^{5} \mathrm{U}$ početnoj fazi prikupljanja podataka sve dobijene informacije tretirane su kao podatak. U kasnijoj fazi prikupljanja podataka primenjujući metodu stalnog upoređivanja i teorijsko uzorkovanje prikupljani su samo podaci u kategorijama za koje je u prethodnim koracima zaključeno da su neophodni za dalje testiranje zaključaka u nastajanju. Rigorozno su ispitani i slučajevi koji nisu podupirali zaključke u nastajanju, te su oni dobijali svoje modifikacije kako je analiza odmicala. Veličina uzorka određena je kriterijumom teorijske saturacije, odnosno odluka o završetku terenskog rada doneta je kada su intervjui prestali da daju nove podatke. 
zivale oko jedne ili više središnjih kategorija (core category) (Corbin i Strauss, 1990). Međusobnim upoređivanjem kategorija i uviđanjem veza između njih izvođeni su zaključci o predmetu istraživanja, te su u zaključnom poglavlju ovog rada prikazani nalazi koji su se gradili „,izranjajući“ iz podataka. U poslednjem koraku analize, vršena su poređenja iskustava različitih sagovornica i sagovornika kako bi se uočili zajednički elementi i razlike među njima, odnosno izdvojili modeli rodne socijalizacije dečaka u porodicama.

$\mathrm{U}$ analizi roditeljskih narativa primenjene su dve tehnike - kategorijska i holistička (Lieblich et al. 1998). U prvom koraku, u okviru tematskih celina koje se odnose na normative o roditeljstvu, vaspitne prakse i porodične odnose, uočene su varijacije u praksama roditelja koje su zatim povezivane sa njihovim socio-ekonomskim i demografskim karakteristikama. U drugom koraku, stalnom uporednom analizom narativa očeva i majki izdvojeni su tipični primeri modela rodne socijalizacije dečaka u savremenim porodicama u Srbiji, a zatim su interpretirani i smešteni na kontinuumu od izrazito tradicionalnih do izrazito modernih vaspitnih praksi i stavova roditelja (očeva i majki).

Proces rodne socijalizacije dečaka u ovom radu ispitan je preko vaspitnih praksi roditelja (koje uključuju roditeljske postupke i stavove) u savremenom društvenom i kulturnom kontekstu Srbije. Modeli rodne socijalizacije dečaka izdvojeni su i interpretirani preko skupa aktivnosti i odnosa u porodici putem kojih roditelji ostvaruju svoje vaspitne ciljeve, a dati vaspitni ciljevi proizlaze iz vrednosti i vaspitnih stavova roditelja. Prateći relaciono određenje procesa socijalizacije u ovom istraživanju, a i da bi se obuhvatile sve promene koje se događaju u okviru savremene porodice i porodičnih praksi (uključujući i ambivalentnosti koje one rađaju), analiza se fokusira na subjektivnu stranu roditeljstva: stavove očeva i majki koji su relevantni za predmet ovog istraživanja, njihove međusobne partnerske odnose i dvosmerne odnose sa decom i drugim članovima i članicama domaćinstva (Olson 1999), kao i na vaspitne prakse roditelja $\mathrm{i}$ načine njihovog prikazivanja sebi i drugima (Finch 2007), to jest značenja koja očevi i majke daju sopstvenim postupcima u procesu rodne socijalizacije. Finč smatra da narativi igraju značajnu ulogu u prikazivanju porodice jer su oni sredstvo putem kojeg ljudi formulišu i komuniciraju sa drugima poimanje vlastitog socijalnog sveta. Kroz narative, ljudi nastoje da povežu sopstvena iskustva i njihovo razumevanje u širu matricu društvenih značenja (Finch 2007, 78). Finč ističe i da je koncept prikazivanja značajan za sve, a ne samo za nekonvencionalne porodične forme. Značaj potiče iz promena u savremenom svetu u kojem se porodica ne definiše više svojom strukturom, već kvalitetom odnosa između pojedinaca (kvalitet komunikacije i rešavanje pitanja iz svakodnevnog života). Pored globalnih promena, na prikazivanje utiču i promene na mikro nivou. Na primer, roditelj će imati drugačije prakse i drugačije će ih prikazivati kako dete odrasta. To zapravo znači da je na snazi proces u kojem i roditelj i dete prime- 
ćuju modifikaciju u promeni njihovog međusobnog odnosa i menjaju načine njihovog prikazivanja.

U ovom radu vaspitne prakse roditelja se prate preko dimenzija brige i kontrole. Iako se analiza oslanja na studiju Dajane Baumrind (1967) koja je definisala tri modela vaspitnih stilova: autoritativni (demokratski), autoritarni i permisivni ${ }^{6}$, kombinujući dimenziju brige i kontrole sa jasnošću komunikacije i zahtevima zrelosti koje roditelji upućuju detetu, u ovom radu se analitički proces bazira na prvim dvema dimenzijama imajući u vidu njihov značaj za predmet ovog istraživanja - rodnu socijalizaciju dečaka. Brojna istraživanja pokazuju da, bez obzira na uzrast deteta, briga i kontrola predstavljaju temelj roditeljskog ponašanja (Darling and Steinberg 1993; Peterson and Rollins 1987). Ipak, odluka da se analiza vaspitnih praksi roditelja bazira na ove dve dimenzije došla je pre svega iz podatka da je najvažniji aspekt procesa rodne socijalizacije dečaka - kontrola „nad sobom, sopstvenim emocijama, društvenim odnosima i kontrola nad drugima" (Stanojević 2018, 56), dok je briga (o drugom) najvažniji aspekt rodne socijalizacije devojčica (Zajović i Kovačević 2012; Ćeriman 2019a).

Polazno stanovište je da je rod konstrukt društveno-kulturnih okolnosti i istorijskog oblikovanja i uslovljavanja zbog čega društvena praksa ističe određene modele maskuliniteta a oni se dalje prenose i transformišu u procesu socijalizacije (Ćeriman 2019a). U skladu s ovom postavkom, pretpostavka je da će stepen reprodukovanja patrijarhalne matrice u stavovima i postupcima roditelja (iskazane kroz zastupljenost rodno segregisanih koncepata dobar roditelj i dobro dete) odrediti i varijacije u modelima rodne socijalizacije dečaka. Na osnovu prisustva, to jest odsustva patrijarhalne matrice, pozicioniraju se na kvalitativnoj analizi zasnovani modeli vaspitnih praksi na kontinuumu od izrazito tradicionalnih vaspitnih praksi do izrazito modernih vaspitnih praksi roditelja.

Izrazito tradicionalne vaspitne prakse roditelja određene su preko prisustva sledećih elemenata u stavovima i postupcima roditelja: familizma (porodica je vrednost po sebi, visoko poštovanje i težnja za očuvanjem porodične tradicije), autoritarnosti, rodnih i starosnih hijerarhija koje predstavljaju liniju odlučivanja i moći (jasna podela poslova u domaćinstvu između muškaraca i žena, dominantan je stav da muškarcu pripada javna sfera, a ženi privatna), bespogovornog poštovanja autoriteta (autoritet poseduju muškarci i stariji članovi domaćinstva), različitog viđenja prirode dečaka i devojčica na čemu se bazira i različit odnos prema njima (devojčice u ponašanju treba da izražavaju skromnost, smernost i poštenje, dok dečaci treba da budu hrabri, odlučni i borbeni), kao i odsustva težnje ka promeni ili prilagodljivosti roditelja na novonastale situacije (otpor prema promenama, glorifikacija prošlosti i tradicije i nostalgija prema prošlosti i tradiciji).

${ }^{6}$ U kasnijem radu (Baumrind 1971) razvija podelu vaspitnih stilova na osam modela. Za ovu podelu dodate su nove dimenzije: strogost, ohrabrivanje nezavisnosti, usmeravanje detetovog ponašanja, punitivno ponašanje i dr. (u oblasti ponašanja roditelja prema detetu) i strogost, autoritarnost, strpljenje, pomanjkanje kontrole i dr. (u oblasti roditeljskih stavova). 
Izrazito moderne vaspitne prakse roditelja (koje uključuju i stavove) određene su preko prisustva sledećih elemenata u stavovima i postupcima roditelja: individualističkog sistema vrednosti (pojedinac je vrednost za sebe, a kolektiviteti su u drugom planu, naglašavaju se slobode i prava pojedinaca, pa time i pravo na lični izbor, poput odluka o razvodu braka, rađanju i sl.), demokratičnosti (podela uloga u domaćinstvu vrši se na osnovu dogovora svih članova i članica porodice, članovi porodice otvorenom komunikacijom dolaze do svih dogovora), gubitka hijerarhija u odnosima i raspodeli moći i autoriteta (tendencija ka izjednačavanju uloga i položaja muškaraca i žena, unutar i izvangeneracijski), podložnosti promenama i prilagođavanju na novonastale situacije (smanjen je autoritet tradicije), u procesu socijalizacije dece roditelji stavljaju naglasak na razvoj ličnosti deteta, u skladu sa potencijalima deteta, bez preskribovanih rodnih određenja.

U poglavlju o analizi sintetički su prikazana i interpretirana tri izdvojena modela rodne socijalizacije dečaka, te smeštena na kontinuumu od izrazito tradicionalnih do izrazito modernih vaspitnih praksi i stavova roditelja (očeva i majki).

\section{Analiza}

U ovom poglavlju prikazana su i interpretirana tri izdvojena modela rodne socijalizacije dečaka. Sva tri modela predstavljena su idealno-tipski, što znači da svaki model dominantno ima karakteristike jednog tipa, s tim da se u njima pojavljuju u većoj ili manjoj meri i elementi koji pripadaju nekom drugom tipu ili drugim tipovima. Prikazani su idealno-tipski prema osnovnim elementima koji ih konstituišu, ali i diferenciraju u odnosu na preostala dva modela, s tim da će među njima biti određenog preklapanja, što takođe predstavlja nalaze u pogledu reprodukovanja patrijarhalne matrice u vaspitnim praksama roditelja. Praćenjem reprodukovanja patrijarhalne matrice, odnosno preko prisustva koncepata dobar otac i dobra majka, te dobar dečak i dobra devojčica u stavovima roditelja, kao i izražene detecentričnosti u roditeljskim praksama, izdvojeni modeli rodne socijalizacije dečaka smešteni su na kontinuumu od izrazito tradicionalnih do izrazito modernih vaspitnih praksi (koje uključuju i stavove) roditelja. Tri izdvojena modela rodne socijalizacije dečaka od izrazito tradicionalnih do izrazito modernih jesu: tradicionalni, prelazni i participativni model.

Tradicionalni model karakteriše jako i dosledno prisustvo svih navedenih koncepata, kako u stavovima roditelja (i očeva i majki), tako i u njihovim praksama, uz izraženu detecentričnost koja se prikazuje kroz isticanje poželjne prvorođenosti sina i stavljanje njegovih potreba iznad potreba roditelja, pri čemu se pre svega očekuje žrtvovanje majke za dete (žrtvujuće roditeljstvo). Porodice iz ovog modela uviđaju promene do kojih dolazi u savremenom društvu, ali su date promene okarakterisane negativno u njihovim narativima te postoji jak otpor pri- 
lagođavanju, kao i jasan zahtev za očuvanjem tradicije, zajednice (familizam) i naučenih modela rodno određenog roditeljstva i rodnosti dečaka/muškaraca. Vrednosti koje stoje u osnovama datih modela obuhvataju kolektivistički sistem vrednosti (brak, porodica, srodnička grupa nalaze se ispred pojedinca), autoritarnost, patrijarhalnu svest, kao i odsustvo promena, odnosno pokretljivosti (čak i fizičke, u smislu da se od sina očekuje da živi u okviru istog domaćinstva u kojem je i njegova primarna porodica). Rodna socijalizacija dečaka u tipičnoj porodici iz ovog modela najviše odgovara karakteristikama života u zatvorenom ,tradicionalnom" društvu (Trebješanin 1991) uz potpuno zanemarivanje promena koje se događaju u okruženju i koje su negativno okarakterisane kao ugrožavanje porodice i porodičnih vrednosti, te je porodica viđena kao utočište $u$ haotičnom društvu (Milić 2001). Iz poimanja porodice kao ,utočišta“" crpi se legitimacija moralne, ali i ideološke ispravnosti članova porodice (Milić 2001, 35), te se stoga zahtevi roditelja pred sina postavljaju kao garant njegovog uspešnog i ispravnog funkcionisanja u savremenom društvu. Dete tako postaje ulaganje u budućnost, pa i budućnost sama (Jenks 1996, 14) što zahteva centriranost porodice oko deteta (detecentričnost porodice), odnosno postavljanje interesa deteta ispred interesa roditelja (žrtvujuće roditeljstvo). Ovakva postavka za sina znači pasivnog učesnika u procesu rodne socijalizacije koji postaje zavistan od roditelja, zaštićen, ali i dužan roditeljima za takvu poziciju, te je na snazi određena ciklična reprodukcija patrijarhalne matrice kojom se ispunjavaju njene osnovne karakteristike: poštovanje starijih i autoriteta tokom čitavog života, kao i primarne porodične zajednice/domaćinstva po sebi. Ranija istraživanja porodica u tradicionalnim društvima upravo pokazuju da roditelji u takvim porodicama vaspitavaju decu strogo u duhu društveno očekivanih vrednosti (Erlih 1971). Glavne vrednosti koje roditelji iz ovog modela prenose na decu jesu: poslušnost, pokornost, disciplina, potčinjavanje autoritetima bez pogovora i sl. U ovom modelu se ističe jasna rodna segregacija normativnih određenja dobra majka i dobar otac preko kojih se na sinove nastoji preneti model poželjnog maskuliniteta, a koji se preko datih određenja konstruiše zahtevom za identifikacijom sa figurom snažnog oca, hranioca i zaštitnika porodice koji nastupa u javnoj sferi, kao i odvajanjem od figure majke koja ima isključivu nadležnost u sferi domaćinstva i čija je uloga prvenstveno ekspresivne prirode (dihotomija javno/privatno, odnosno kultura/ priroda). Navedeni koncepti zamišljeni su kao dva pola na rodnom kontinuumu i uz to su međusobno komplementarni. Socijalizacija dečaka odvija se između ovih normiranih polova tako što se očekuje identifikacija sinova sa dobrim ocem i njegovo simboličko odvajanje od dobre majke, odnosno njegovo prevođenje iz sveta prirode u svet kulture (Ortner 1974). Poželjni maskulinitet koji se na ovaj način konstruiše podrazumeva ličnost deteta koje jednog dana treba da nastavi porodičnu tradiciju, odnosno da primeni naučene modele ponašanja i verovanja bez njihove transformacije $\mathrm{u}$ određenom istorijskom i kulturnom kontekstu. 
Kontrola čini najvažniji element u konstruisanju maskuliniteta u ovom modelu, dok je dimenzija brige viđena kao ženski domen (muškarac ima instrumentalnu ulogu, a žena ekspresivnu ulogu u porodici). Svakodnevicu porodica iz ovog modela karakteriše jasna podela na privatnu (žensku) i javnu (mušku) sferu, pa tako majka ima zaduženja koja se tiču poslova u domaćinstvu i brige o deci i neretko starim i onemoćalim članovima porodice, dok je otac orijentisan na sferu rada izvan domaćinstva, odnosno igra ulogu hranioca porodice i glavnog donosioca prihoda. Određenje oca kao hranioca porodice uslovljava njegovu konstantnu zauzetost radi obezbeđenja materijalnih sredstava za život porodice, pa u nedostatku slobodnog vremena jedine aktivnosti koje ima sa sinom podrazumevaju njegovo jasno uvođenje u rodnu ulogu (na primer, dvogodišnji dečak češće provodi vreme izvan kuće prateći oca u njegovim aktivnostima, dok s druge strane, četvorogodišnja ćerka iz iste porodice pomaže majci u nezi dede). Otac iz ovog modela podjednako je autoritet i partnerki i deci. Majka je zadužena za vaspitavanje dece, pre svega ćerki, u duhu tradicionalnih moralnih vrednosti čiju kontrolu vrši otac (na primer, već na uzrastu dece iz prethodnog primera obraća se pažnja na njihovu seksualnost, te se ćerka savetuje da se „sklanja“ i ,skriva“ od muških članova porodice). Majke su reprezent mesta koje sinovi treba da prevaziđu u procesu socijalizacije kako bi dostigli ideal snažnog oca, zaštitnika i hranioca porodice. Dok je pozicija majke transparentna i uvek dostižna sinovima, budući da majka čeka na istom mestu podrške „na koje se sin uvek može vratiti“ (citat, prim. aut.), dotle je pozicija oca sačinjena od „mitova o džinovima“ (citat, prim. aut.), nedohvatnim figurama koje nanovo treba osvajati poštovanjem pravila i hijerarhija koje vladaju u domaćinstvu. Zahtev za identifikacijom sa modelom dobrog oca podrazumeva poštovanje i poslušnost nepisanim pravilima i davno uspostavljenim autoritetima (na rodnoj i starosnoj osnovi) koji u konačnici donose dividendu maskuliniteta (Connell 2005), odnosno dobit od dostignute povlašćene pozicije. Stoga je postavljene norme neophodno poštovati bez preispitivanja i refleksije na promene u okruženju budući da se jedino njihovom doslednom primenom i neprikosnovenim stavom može dostići pozicija u vrhu postavljenih hijerarhija, koje su istovremeno i unutrašnje i spoljašnje u odnosu na roditelje. Naime, norme se čuvaju sistemom simboličkih značenja u čijem održanju učestvuju i oni koji su na vrhu, ali i oni sa dna lestvice, te je od izuzetne važnosti biti dosledan u njihovom poštovanju jer to znači i sticanje određenog ugleda u dobrom obavljanju rodne uloge (kako za muškarce, tako i za žene). Iako je priroda poštovanja i čuvanja normi u okviru ovog modela različita u zavisnosti od toga na kom kraju lestvice se nalazi određena osoba (sin ili ćerka, otac ili majka) zapravo je reč o istom skupu osobina i postupaka koji su neophodni za ovu vrstu akcije: submisivan stav prema autoritetu, konformizam, tradicionalizam, podržavanje familističke ideologije i heteronormativizam. Vaspitne prakse roditelja iz ovog modela karakteriše stroga kontrola ponašanja sina (koja raste sa 
uzrastom deteta i reguliše ponašanje u pravcu rodno očekivanih modela) uz slabo iskazivanje emotivne topline, što prema tipologiji Baumrind (Baumrind 1967) odgovara najpre autoritarnom vaspitnom stilu roditelja. Sinovi iz ovog modela se podstiču na praktikovanje rodno tipičnih aktivnosti i ponašanja, a kažnjavaju kada njihovo ponašanje ne odgovara rodno tipiziranom modelu iz vaspitnog cilja roditelja, što se dosledno sprovodi kako na individualnom nivou, tako i na nivou roditeljskog para, kao i u praksi drugih članova domaćinstva koji učestvuju u procesu rodne socijalizacije, uz često korišćenje javnog moralnog nazora kao sredstva dodatne prinude na povinovanje određenim modelima. Disciplinovanje raste sa uzrastom dece upravo zbog navedene socijalne poželjnosti određenih rodnih prikazivanja. Emotivna strana socijalizacije dečaka u ovom modelu izostaje (ispitivana preko dimenzije brige), osim kada je neophodno postići postavljene vaspitne ciljeve kombinovanim sistemom zastrašivanja (kako bi se prevenirali negativni postupci kršenja normi) i stida/sramote (u situaciji kada su načinjeni blaži prekršaji pravila). Sinovima iz porodica iz ovog modela najčešće nije dozvoljeno ni iskazivanje emocija, poput plača, čak i kada je reč o dvogodišnjim dečacima. Ovakav stav češće izražavaju očevi nastojeći da sina „očeliče“ (citat, prim. aut.) za život u društvu i razviju osobine koje karakterišu buduću autoritarnu glavu porodice. Budući da se patrilinearnost poštuje kao vrhunska vrednost, rođenje sina znači i vrednost dečaka samog po sebi, a provorođenost sina donosi i vrednost majci u ovako postavljenim hijerarhijama, jer je već sa prvim detetom obezbedila kontinuitet porodične tradicije. U situaciji kada je devojčica prvorođena, veći pritisak je bio stavljen na ženu usled povećanog očekivanja da naredno dete bude dečak. Partnerski odnos roditelja predstavlja i model putem koga se prenosi zahtev za heteronormativnošću koji je dodatno potpomognut međusobnim „muškim“ razgovorima oca i sina (poput sporta, seksualnosti, odnosa sa ženama i sl.). Partnerski odnos roditelja iz ovog modela oslobođen je iskazivanja intime i bliskosti jer za nju nema prostora u proširenom domaćinstvu, a zbog čvrsto postavljenih uloga, porodični odnosi nisu podložni pregovaranju i dogovorima, te ne postoji prostor za transformaciju zatečenih obrazaca ponašanja i mišljenja koji sa protokom vremena ulaze u rutinizovano ponašanje i dovode do reprodukcije postojeće (patrijarhalne) matrice. Tipični primer tradicionalnog modela u ovom istraživanju predstavlja proširena porodica iz ruralnog područja koja je sačinjena od tri generacije: porodice porekla muža, porodice opredeljenja koju čini bračni par - nezaposlena majka sa završenom osnovnom školom i otac sa završenom srednjom školom koji radi na poziciji kvalifikovanog radnika i njihova deca.

Prelazni model socijalizacije dečaka karakteriše pre svega ambivalentan odnos između zaštićenosti deteta od rizika koji dolaze iz društvenog okruženja i želje roditelja da pripreme sina za funkcionisanje u savremenom društvu u kom 
primećuju promene. Roditelji iz ovog modela na sina gledaju kao na „projekt“ (Milić 2001, 161-162), te nastoje da umesto sopstvenog delovanja u ime deteta, uspostave sina kao delatnog subjekta u savremenom društvu. U tom smislu, vaspitne prakse roditelja u procesu rodne socijalizacije dobijaju izvesnu modifikaciju usled uviđanja da određeni modeli funkcionisanja ne odgovaraju percepiranim društvenim promenama. Vrednost deteta kao projekta u porodici - tipičnom predstavniku ovog modela dolazi i usled toga što funkcionalnost sina u socijalnom životu izvan porodice potvrđuje i njihovu uspešnost kao roditelja. Dečak tako postaje simbolička reprezentacija društva, te preko njega roditelji nastoje da prevaziđu sopstvene nesigurnosti i rizike današnjice (Milić 2001). Roditelji stoga konstantno upoređuju svoje vaspitne prakse sa normativima okruženja ili takozvanim komparatorima kada je reč o rodnim identitetima (Burke and Stets 2009, 74-75), nastojeći da postignu funkcionalne efekte procesa rodne socijalizacije sina. Stoga u ovom modelu neminovno dolazi do reprodukcije određenih rodnih konstrukata iz društvenog konteksta koji čini predmet ovog istraživanja. Iskorak u pravcu modernosti u odnosu na prvi prikazani obrazac ogleda se u detradicionalizaciji roditeljstva koje ide u pravcu napuštanja žrtvujućeg modela majčinstva, a samim tim i napuštanja detecentričnosti porodice. Koncept dobre majke u ovom modelu prestaje da bude mesto konstantne i beskompromisne otvorenosti za povratak sina u sferu privatnosti, odnosno u utočište iz haotičnog spoljneg sveta kojem sin pripada svojim rodnim određenjem. Ipak, ovim konceptom koji stoji u komplementarnom odnosu sa konceptom dobrog oca zadržava se visoko vrednovanje porodice kao zajednice po sebi, odnosno zajednice sa određenom formom, te se ona postavlja kao norma za budući život sina i poželjna projekcija njegove porodice opredeljenja. Majka i otac, budući komplementarne figure, predstavljaju dva pola jedne slike sveta. Majka je i u ovom modelu zadužena za privatnu sferu, ali sa znatno više moći negoli žena iz tradicionalnog modela. Na ovaj način dolazi ne samo do detradicionalizacije roditeljstva, već i dekonstrukcije stereotipno viđene uloge žene, brižne negovateljice. Tako se zapravo dva pola u rodno obojenom svetu polako približavaju jedan drugom što opušta i čvrsto postavljene okvire rodnog identiteta sina koji se nastoji konstruisati vaspitnim praksama roditelja. Majka i otac s ovom promenom dobijaju znatno više tačaka preseka između sfera u kojima su nadležni jer se povlačenjem majke iz određenih aktivnosti u domaćinstvu otvara prostor za većim uključivanjem oca u obavljanje zaduženja u privatnoj sferi, uključujući i brigu i staranje o deci. Na ovaj način se pred očima deteta transformišu ustaljeni modeli porodičnih praksi i pruža mogućnost identifikacije sa modifikovanim konceptom dobrog oca. Dobri otac u ovom modelu zadržava odlike snažnog muškarca, zaštitnika porodice, ali razvija i (nove) odlike dobrog i prilagodljivog partnera u odgovoru na novonastale promene u domaćinstvu. U ovom istraživanju do takvih promena je najčešće dolazilo usled toga što je majka zauzela 
aktivnu ulogu u pregovorima za novu raspodelu obaveza i odgovornosti u porodici usled opšteg iscrpljivanja vlastitih resursa. Napuštanje žrtvujućeg modela majčinstva zahteva veće uključenje oca u poslove u domaćinstvu, pa partnerske odnose u porodicama iz ovog modela karakteriše prilagođavanje novonastalim promenama do kojih se došlo u dužem vremenskom periodu kroz međusobne dogovore i pregovaranja supružnika. Dinamika partnerskog odnosa time dobija na izvesnom preokretu u pravcu, „žrtvovanja“ oca, odnosno njegovog odricanja od jednog dela privilegija koje je uživao pre ulaska u zaduženja u sferi privatnog. Sličnost sa prvim modelom ogleda se u zadržavanju rodno segregiranih određenja koncepta dobar roditelj kojima se nastoje preneti heteronormativne vrednosti na sinove, kao i u visokom vrednovanju zajednice (familizam). Nakon što se ova baza učvrsti sistemom nagrada i kazni, roditelji dopuštaju slobodno odlučivanje i delanje sina u pravcu poželjne budućnosti. Ipak, budući da se roditelji iz ovog modela vode pravilom ,zlatne sredine“ (citat, prim. aut.), radi navedene težnje za formiranjem sina koji će biti funkcionalna jedinka u društvu, konformizam čini glavno obeležje njihovih vaspitnih ciljeva, a model maskuliniteta po svojim obeležjima sledi hegemoni model maskuliniteta (Connell 2005, 37) u socijalnoj i kulturnoj sredini u kojoj se odvija proces rodne socijalizacije. Prakse koje odstupaju od datog modela u ovim porodicama pravdaju se izuzetnim slučajevima (izuzecima nastalim pod uticajem specifičnih okolnosti) i prikazuju (displaying) ka spolja u skladu sa socijalnom poželjnošću (na primer, stidljivost sina se pravda time što je mlađe dete u porodici, dok se proaktivan stav ćerke tumači prvorođenošću iako je starosna razlika dece u toj porodici samo godinu dana). Prikazivanje praksi na socijalno poželjan način vodi i u njihovu nedoslednost (normativnu i praktičnu) kako na individualnom nivou, tako i na nivou roditeljskog para, te analiza ukazuje i na izostanak pravilnosti odnosa roditelj-dete po dimenzijama brige i kontrole. Partnerski odnos roditelja iz ovog modela bazira se na iskazivanju međusobne intime i bliskosti, čime se on dodatno učvršćuje i pravi prostor za dalji lični i partnerski razvoj. Međutim, iako su porodični odnosi podložni pregovaranju i dogovorima, njih ne karakteriše otvorenost, već se odluke donose u izvesnoj hijerarhijskoj situaciji u zavisnosti od toga koliku percepiranu moć može imati određena odluka na preraspodelu ukupne moći u domaćinstvu. Deca retko učestvuju u donošenju odluka u domaćinstvu, čak i kada ih se određene teme tiču. Ne postoji ni doslednost u odlukama već se često mora nanovo pregovarati oko dogovora koji su već doneti. Od sina se očekuje da se identifikuje sa modelom oca koji zadržava odlike snažnog muškarca, glave porodice, koji je ujedno i zaštitnik porodice (te je dimenzija kontrole i ovde vrlo važna), ali i razvija (nove) odlike prilagodljivog partnera u odgovoru na novonastale promene u domaćinstvu (pri čemu se dimenzija brige prvenstveno ogleda u ispomoći partnerki u obavljanju poslova u domaćinstvu kada ona to nije u mogućnosti da obavi, najčešće zbog partnerkine bolesti, pre 
nego u samoinicijativnom uključivanju u aktivnosti u domaćinstvu). Roditelji iz ovog modela su nezahtevni, relativno topli i vrše manju kontrolu sina od prethodno navedenog modela, a često su i nedosledni u svojim vaspitnim praksama. Ne postoji jaka doslednost ni između vaspitnih ciljeva i vaspitnih praksi roditelja prema sinovima (ni pojedinačno, a ni kao roditeljski par) što se može objasniti izvesnom posledicom modifikacije rodno određenog koncepta dobar roditelj koji ima efekte i na modifikaciju koncepta dobar dečak, a samim tim i na odnose roditelja sa sinom. Ova doslednost vidljiva je u dimenziji kontrole, gledano prema podršci samostalnosti sina, kao i prema nagrađivanju i kažnjavanju sina. Prostor za transformaciju zatečenih obrazaca ponašanja i mišljenja tako se kreće između hijerarhija koje postoje izvan porodičnog domena, uslovno rečeno, i onih koje se reprodukuju u međusobnim relacijama članova i članica porodice. Tipični primer prelaznog modela u ovom istraživanju predstavlja porodica koju čini bračni par: zaposlena majka i otac, oboje sa srednjom stručnom spremom, koji žive u urbanoj sredini.

Participativni model pre svega karakteriše traženje novih odgovora na promene koje se primećuju u okruženju, te razvoj ličnosti dečaka koji će biti sposoban da samostalno odlučuje i donosi izbore u pravcu ,otvorene budućnosti“" (Bobić 2013). Pored toga, karakteriše ga i individualizacija roditeljstva u pravcu napuštanja žrtvujućeg majčinstva i očinstva i njihove transformacije u skladu sa percepiranim promenama u određenom istorijskom i kulturnom kontekstu, ali i nasuprot iskustvu roditeljstva koje su imali priliku da vide u porodici porekla, te u tom smislu predstavlja izvesnu modifikaciju nasleđenih porodičnih praksi. U ovom modelu je naizrazitija dekonstrukcija rodno određenog koncepta dobar roditelj pri čemu se prisustvo patrijarhalne matrice u ovom modelu može primetiti u zadržavanju normativa o rodno segregisanim sferama na javno (koje pripada muškarcu) i privatno (koje pripada ženi). I u ovom modelu se zadržava visoko vrednovanje porodične grupe kao takve (familizam), pre svega zbog komplementarno sagledanih uloga majke i oca u porodici. Detradicionalizacija roditeljstva se tako ogleda isključivo u napuštanju žrtvujućeg modela roditeljstva, jer ideologija familizma povezana sa heteronormativnošću i dalje konstruiše kontekst odrastanja dečaka u ovoj porodici (videti detaljniju interpretaciju u Ćeriman 2019a; 2019b). Roditelji iz ovog modela imaju individualizovani pristup deci, odnosno sinove posmatraju kao osobe s određenim osobinama i potencijalima te nastoje da ih podrže u razvoju uz jasne granice (roditeljska perspektiva ima primat, ali postoji i uvažavanje perspektive deteta) i izraženu emotivnu toplinu. Sinovi takođe učestvuju u procesima odlučivanja u domaćinstvu oko stvari koje ih se tiču i podržani su da iskazuju sopstveno mišljenje pa tako kreiraju dvosmernost socijalizacije. Roditelji na osnovu interakcija sa sinom prilagođavaju sopstvene vaspitne prakse. Na primer, jedna od sagovornica iz porodice koja pripada ovom modelu je tokom intervjua napra- 
vila osvrt na sopstveno učešće u različitim istraživanjima socijalnih fenomena naglašavajući da je i to jedan vid otvaranja porodice ka javnosti i preispitivanje roditeljskih postupaka i stavova. Dodatni iskorak u pravcu modernosti u odnosu na drugi (prelazni) model u participativnom modelu je vidljiv u izrazitoj kohezivnosti, bliskosti i fleksibilnosti partnera koji do svih odluka u domaćinstvu dolaze zajedničkim dogovorom i dosledno se drže odluka o kojima je prethodno načinjena saglasnost. Do promena u sferi domaćinstva dolazi usled sposobnosti kritičke refleksije supružnika i zauzimanja aktivnog stava u pravcu poželjne budućnosti. U svojim vaspitnim praksama su dosledni, kako na individualnom nivou, tako i na nivou roditeljskog para, a život $u$ odvojenom domaćinstvu u odnosu na porodicu porekla omogućava im razvoj i usaglašavanje njihovih vaspitnih ciljeva. U odnosu sa sinom iskazuju jasne granice uz emotivnu podršku, te se vaspitni stil roditelja iz ovog modela najpre može odrediti kao demokratski, prema tipologiji Baumrind (Baumrind 1967). Rodna socijalizacija dečaka u ovoj porodici odvija se u odnosu prema porodičnom kontekstu prošlo, aktualno i prospektivno, a u određenoj meri i prema percepiranim društveno-istorijskim i kulturnim promenama dugog trajanja. U ovakvoj porodičnoj dinamici, kroz izrazitu emocionalnu toplinu i blagu kontrolu dobre majke i dobrog oca konstruiše se poželjni tip maskuliniteta, pri čemu je fokus na izgradnji veština i znanja koje će omogućiti samostalno donošenje odluka i pravljenje izbora koji će voditi u pravcu dobrog i srećnog života u savremenom društvu, uz zadržavanje osobina koje karakterišu dobrog oca, budući da se i u ovom modelu socijalizacija vrši preko procesa identifikacije s ocem, a „odvajanja" od dobre majke. Poželjni maskulinitet koji se na ovaj način konstruiše podrazumeva ličnost deteta od kog se očekuje da se identifikuje sa modelom oca koji zadržava primat $\mathrm{u}$ javnoj sferi u odnosu na majku (muškarac/otac je simbolički prelaz između javnog i privatnog sveta), ali i koji je prilagodljiv i dobar partner spreman da razvija i primenjuje nove odgovore na promene koje primećuje u savremenom društvu i koji podjednako učestvuje u poslovima u domaćinstvu. Konstrukcija maskuliniteta prevazilazi funkciju oca unutar porodice i zauzima poziciju aktivnog učesnika u društvu koji učestvuje u promenama lokalne zajednice (na primer, u jednoj porodici iz ovog modela je izuzetno značajna borba i inicijativa za bezbedne i uređene biciklističke staze $u$ gradu). Kada je reč o ispitanim dimenzijama brige i kontrole, u ovom modelu emocionalna socijalizacija sina čini važan element procesa rodne socijalizacije i definiše se kao sposobnost osećaja sebe i drugih sa kojom se ulazi u socijalne relacije, dok je dodatno, s uviđanjem promena u društvu, smanjen zahtev za kontrolom i modifikovan u pravcu osposobljavanja dečaka za samostalan život i donošenje odluka/pravljenje izbora u pravcu kreiranja sopstvene budućnosti. Tipični primer participativnog modela u ovom istraživanju predstavlja porodica koju čini bračni par: visokoobrazovana majka i otac sa završenom srednjom školom, oboje zaposleni na poziciji stručnjaka, koji žive u urbanoj sredini. 


\section{Diskusija}

Predmet istraživanja $\mathrm{u}$ ovom radu je proces porodične rodne socijalizacije dečaka u savremenom društveno-kulturnom kontekstu Srbije putem analize vaspitnih praksi (postupaka i stavova očeva i majki). U skladu s osnovnom pretpostavkom u ovom radu da su stavovi roditelja oblikovani društvenim i kulturnim kontekstom Srbije, očekivanje je da će reprodukovanje patrijarhalne matrice u stavovima roditelja odrediti i varijacije u roditeljskim praksama u procesu rodne socijalizacije dece. Reprodukovanje patrijarhalne matrice u ovom radu praćeno je kroz rodno segregisan koncept dobar roditelj, odnosno dobra majka i dobar otac, kao i kroz rodno segregisan koncept dobro dete (pri čemu su ćerke činile kontrolnu grupu u ovom istraživanju), budući da su ovi koncepti podržani društveno-kulturnim i istorijskim kontekstom u kojem roditelji žive. Na osnovu praćenja reprodukcije patrijarhalne matrice, izdvojena su tri modela rodne socijalizacije dečaka: tradicionalni, prelazni i participativni.

Istraživanje je pokazalo da je u većini vaspitnih praksi očeva i majki dečaka u porodicama u savremenoj Srbiji prisutno reprodukovanje patrijarhalne matrice, koje je iskazano kroz rodno segregisane koncepte dobar roditelj i dobro dete, a podržano je društveno-kulturnim i istorijskim kontekstom društva Srbije, kao i da dva izdvojena modela (prelazni i participativni model) predstavljaju iskorak u pravcu individualizacije roditeljstva i egalitarnijih vaspitnih praksi u procesu porodične rodne socijalizacije.

Istraživanje je pokazalo da su rodno segregisani koncepti dobar roditelj $\mathrm{i}$ dobro dete zastupljeni kod subjekata istraživanja koji su nižeg obrazovnog statusa (osnovna ili srednja škola), koji su zaposleni na radničkim pozicijama ili nezaposleni i češće žive u ruralnim oblastima, kao i u proširenim porodicama. Rodno segregisan koncept dobro dete preispituje se i počinje njegova dekonstrukcija kod dela zaposlenih visokoobrazovanih roditelja iz urbanih sredina. Ipak, analiza je pokazala da će varijacije modela rodne socijalizacije dečaka pre svega zavisiti od specifičnih odnosa koji su uspostavljeni između supružnika, odnosno da veći stepen bliskosti, fleksibilnosti i bolja komunikacija između supružnika vode i egalitarnijim vaspitnim praksama roditelja u procesu rodne socijalizacije (slično ističu i studije: Stanojević 2015; Tomanović, Stanojević, Ljubičić 2016). Dinamika partnerskog odnosa time zapravo dobija na izvesnom preokretu u pravcu ,žrtvovanja“ oca, odnosno odricanja oca od jednog dela privilegija koje je uživao pre preuzimanja zaduženja u domaćinstvu. Uvođenje sina u ovu rodnu ulogu sada u jednom delu mogu zajedno vršiti otac i majka, te se usaglašenošću njihovih vaspitnih praksi osigurava i više prostora za transfer modifikovanih rodnih normi. Viši kvalitet partnerskog odnosa i interakcije sa društvenom sredinom i percepiranim promenama u njoj, odnosno konsenzus supružnika oko vaspitnih praksi koje će ići u pravcu prilagođavanja uočenim 
društvenim promenama, čine glavne elemente $u$ čijem međusobnom odnosu se grade egalitarnije vaspitne prakse roditelja i odvija socijalizacija dečaka koja ide u pravcu razvoja otvorene ličnosti deteta (videti Ćeriman 2019a). U porodicama u kojima se očitava otpor prema promenama ne dolazi do preispitivanja rodno segregisanog koncepta dobro dete, dok u porodicama koje razvijaju nove odgovore na percepirane promene dolazi do detradicionalizacije koncepta $d o-$ bar dečak.

Iako se nalazi ovog kvalitativnog istraživanja ne mogu generalizovati, oni ipak ukazuju na značenja koja roditelji pridaju sopstvenim vaspitnim praksama u procesu socijalizacije dečaka. Istovremeno, ovim istraživanjem je dat doprinos promišljanjima specifičnosti konteksta roditeljstva u Srbiji, odnosno razmatranjima mogućnosti transformacije dominantnog modela južnoevropske familističke porodične solidarnosti u praksi (Tomanović 2017; Stanojević 2015). Budući da individualizacija roditeljstva nije podržana ni kao kulturni normativ, ni kao praksa u ovom regionu, roditeljima se ne pružaju novi modeli na koje je moguće ugledati se i ubrzati proces detradicionalizacije roditeljstva. Ipak, ovo istraživanje je pokazalo, poput nekih ranijih istraživanja (Stanojević 2015; Tomanović, Stanojević, Ljubičić 2016), da nove prakse roditeljstva mogu nastati s implicitnim konsenzusom para oko rodno egalitarnih vrednosti. Navedene interakcije imaju snagu delatnog potencijala jer ukazuju na mogućnost promene stavova i praksi pojedinačnih osoba i roditeljskog para.

\section{Literatura}

Babović, Marija, Dragan Stanojević, Jelena Milinović, Irena Petrović, Stefan Stefanović. 2016. Rodne nejednakosti u Republici Srpskoj iz perspektive životnih tokova. Banja Luka: Gender centar - Centar za jednakost i ravnopravnost polova Vlade Republike Srpske.

Baumrind, Diana. 1967. „Child Care Practices Anteceding Three Patterns of Preschool Behavior.“ Genetic Psychology Monographs 75 (1): 43-88.

Baumrind, Diana. 1971. „Current patterns of parental authority.“ Developmental Psychology 4 (1, Pt.2): 1-103. https://doi.org/10.1037/h0030372

Bek, Ulrich. 2001. Rizično društvo. Beograd: Filip Višnjić.

Bek, Ulrich. 2003. ,Živeti sopstveni život u svetu koji se ubrzano menja: individualizacija, globalizacija i politika“. U Na ivici. Živeti sa globalnim kapitalizmom, uredili Vil Haton, Entoni Gidens, 216-229. Beograd: Plato.

Ber, Vivijen. 2001. Uvod u socijalni konstrukcionizam. Beograd: Zepter book world.

Berger, Peter, Thomas Luckmann. 1991. The Social Construction of Reality: A Treatise in the Sociology of Knowledge. London: Penguin Books.

Bobić, Mirjana. 2003. „Prekomponovanje braka, partnerstva i porodice u savremenim društvima.“ Stanovništvo 1-4: 65-91. http://www.doiserbia.nb.rs/img/doi/0038982x/2003/0038-982X0304065B.pdf 
Bobić Mirjana. 2013. Postmoderne populacione studije. Demografija kao intersekcija. Beograd: Institut za sociološka istraživanja Filozofskog fakulteta i Čigoja štampa.

Bodroški Spariosu, Biljana. 2010. Postupci roditelja u vaspitanju dece i njihov međugeneracijski transfer. Beograd: Univerzitet, Filozofski fakultet.

Bordo, Susan. 2003. „Tijelo i reprodukcija ženstvenosti. Rekonstrukcija feminističkog diskurza o tijelu." Razlika/Differance, Časopis za kritiku i umjetnost teorije 2 (3-4): 311-331.

Boychuck, Duchscher Judy \& Morgan, Debra (2004). „Grounded Theory: Reflections on the Emergence vs. Forcing Debate." Journal of Advanced Nurcing 48 (6): 605612. https://doi.org/10.1111/j.1365-2648.2004.03249.x

Burke, Peter J., Jan E. Stets. 2009. Identity Theory. New York: Oxford University Press. Butler, Judith. 2005. Raščinjavanje roda. Sarajevo: TKD Šahinpašić.

Connell, Raewyn. (1995) 2005. Masculinities. Berkeley and Los Angeles: University of California Press.

Corbin, Juliet, Anselm Strauss. 1990. „Grounded Theory Research: Procedures, Canons and Evaluation Criteria." Qualitative Sociology 13(1): 3-21. URL: https://med-fom-familymed-research.sites.olt.ubc.ca/files/2012/03/W10-Corbin-and-Strauss-grounded-theory.pdf

Ćeriman, Jelena. 2019a. ,Rodna socijalizacija dečaka u porodicama u savremenoj Srbiji. Istraživanje stavova i vaspitnih praksi roditelja." Doktorska disertacija, Filozofski fakultet Univerziteta u Beogradu.

Ćeriman, Jelena. 2019b. „The Limits of Individualizing Parenthood in Serbia: Study of Gender Socialization of Children." Philosophy and Society 30(3): 321-462. http:// www.doiserbia.nb.rs/img/doi/0353-5738/2019/0353-57381903399C.pdf

Darling, Nancy, Laurence Steinberg. 1993. „Parenting Style as Context: An Integrative Model.“ Psychological Bulletin 113 (3): 487-496. https://doi.org/10.1037/00332909.113.3.487

Erlih, Vera. 1971. Porodica u transformaciji. Zagreb: Naprijed.

Finch, Janet. 2007. „Displaying Families.“ Sociology 41(1): 65-81. https://doi. org/10.1177/0038038507072284

Giddens, Anthony. (1984) 1989. The Constitution of Society. Cambridge: Polity Press and Blackwell Publishing Ltd.

Glaser, Barney G. and Strauss, Anselm L. 1967a. Awarness of Dying, Chicago: Aldine Publishing Company.

Glaser, Barney G. and Strauss, Anselm L. 1967b. The Discovery of Grounded Theory: Strategies for Qualitative Research, New Brunswick and London: Aldine Transaction.

Graorac, Isidor. 2016. „Implicitna pedagogija i svakidašnji život odraslih i dece.“ U Zbornik radova sa interdisciplinarne naučnostručne konferencije sa međunarodnim učešćem ,Svakodnevni život deteta”, 17-19. novembra 2016, Novi Sad, uredila Lada Marinković, 125-139. Novi Sad: Visoka škola strukovnih studija za obrazovanje vaspitača.

Jenks, Christopher. 1996. „Postmodern Child.“ In Children in Families, Research and Policy, edited by Julia Brannen, Margaret O’Brien, 13-25. London: Routledge. 
Kimmel, Michael. 2009. „Guyland: Gendering the Transition to Adulthood.“ In Men's Lives (eighth edition), edited by Michael S. Kimmel, Michael A. Messner, 107-120. Boston: Allyn \& Bacon.

Lieblich, Amia, Rivka Tuval-Mashiach, Tamar Zilber. 1998. Narrative Research: Reading, Analysis and Interpretation. London: Sage Publications.

Milić, Anđelka. 2001. Sociologija porodice: kritika i izazovi. Beograd: Čigoja.

Milić, Anđelka. 2010a. „Porodica i izazovi globalne transformacije.“ U Vreme porodica: Sociološka studija o porodičnoj transformaciji u savremenoj Srbiji, uredili Anđelka Milić, Smiljka Tomanović, Milana Ljubičić, Nada Sekulić, Mirjana Bobić, Vesna MIletić-Stepanović, Dragan Stanojević, 13-32. Beograd: Čigoja štampa: Institut za sociološka istraživanja Filozofskog fakulteta.

Milić, Anđelka. 2010b. „Porodične vrednosne orijentacije - Vrednosni raskol.“ U Vreme porodica: Sociološka studija o porodičnoj transformaciji u savremenoj Srbiji, uredili Anđelka Milić, Smiljka Tomanović, Milana Ljubičić, Nada Sekulić, Mirjana Bobić, Vesna MIletić-Stepanović, Dragan Stanojević, 235-256. Beograd: Čigoja štampa: Institut za sociološka istraživanja Filozofskog fakulteta.

Milić, Anđelka, Smiljka Tomanović, Milana Ljubičić et al. 2010. Vreme porodica: Sociološka studija o porodičnoj transformaciji u savremenoj Srbiji. Beograd: Čigoja štampa: Institut za sociološka istraživanja Filozofskog fakulteta.

Mladenović, Uroš. 1976. „Uloga pola kome dete pripada i prihvatanje te uloge.” Magistarski rad. Filozofski fakultet Univerziteta u Beogradu.

NFPI (National Family \& Parenting Institute). 2001. Listening to Parents. Their Worries, Their Solutions. Report 10/2001. London: NFPI.

Olson, David H. 1999. „Circumplex Model of Marital \& Family Systems (Empirical Approaches to Family Assessment).“ Journal of Family Therapy, special edition, 144-167. URL:https://www.uwagec.org/eruralfamilies/ERFLibrary/Readings/CircumplexModelOfMaritalAndFamilySystems.pdf

Ortner, Sherry. 1974. „As Female to Male as Nature is to Culture?“ In Woman, Culture and Society, edited by Michelle Z. Rosaldo \& Louise Lamphere, 68-87. Stanford: Stanford University Press.

Petrović-Piorkowska, Katarzina. 1990. Dete u nepotpunoj porodici. Beograd: Prosveta. Radulović, Lidija. 2009. Pol/Rod i religija: konstrukcija roda u narodnoj religiji Srba. Beograd: Srpski genealoški centar: Odeljenje za etnologiju i antropologiju Filozofskog fakulteta.

Stanojević, Dragan. 2015. „Oblikovanje novog očinstva kroz prakse očeva u Srbiji.“ Doktorska disertacija, Filozofski fakultet Univerziteta u Beogradu.

Stanojević, Dragan. 2018. Novo očinstvo u Srbiji: sociološka studija o praksama i identitetima očeva. Beograd: Institut za sociološka istraživanja Filozofskog fakulteta.

Tomanović, Smiljka. 1993. „Socijalizacija kao praksa socijalne reprodukcije u delima Entoni Gidensa i Pjera Burdijea." Sociološki pregled XXVII (1-4): 303-315. URL: https://rive.google.com/file/d/0B5PfUtWAVbsKMUpHM2xGRGtaVTA/view

Tomanović-Mihajlović, Smiljka. 1997. Detinjstvo u Rakovici: svakodnevni život dece u radničkoj porodici. Beograd: Institut za sociološka istraživanja Filozofskog fakulteta.

Tomanović, Smiljka. 2010. „Odlike roditeljstva.“ U Vreme porodica: Sociološka studija o porodičnoj transformaciji u savremenoj Srbiji, uredili Anđelka Milić, Smiljka To- 
manović, Milana Ljubičić, Nada Sekulić, Mirjana Bobić, Vesna MIletić-Stepanović, Dragan Stanojević, 177-194. Beograd: Čigoja štampa: Institut za sociološka istraživanja Filozofskog fakulteta.

Tomanović, Smiljka, Milana Ljubičić, Dragan Stanojević. 2014. Jednoroditeljske porodice u Srbiji - sociološka studija. Beograd: Institut za sociološka istraživanja Filozofskog fakulteta: Čigoja štampa.

Tomanović, Smiljka, Dragan Stanojević. 2015. Mladi u Srbiji 2015. Stanja, opažanja, verovanja i nadanja. Beograd: Friedrich Ebert Stiftung: SeConS.

Tomanović, Smiljka. 2017. „Roditeljstvo između familizma i individualizacije: primer Srbije." U Individualizam, uredili Suzana Ignjatović, Aleksandar Bošković, 162181. Beograd: Institut društvenih nauka.

Trebješanin, Žarko. 1991. Predstava o detetu u srpskoj kulturi. Beograd: Srpska književna zadruga.

Šmale, Volfgang. 2011. Istorija muškosti u Evropi (1450-2000). Beograd: Klio. Zajović, Staša, Ljupka Kovačević, ur. 2012. Feministička etika brige: čitanka/reader. Beograd: Žene u crnom: Anima.

Jelena Ćeriman Institute for Philosophy and Social Theory, University of Belgrade, Serbia

\section{Models of Boys' Gender Socialization in Families in Modern-day Serbia}

This paper focuses on the process of gender socialization of boys, examined through parenting practices of mothers and fathers in the contemporary socio-cultural context of Serbia. The analysis is based on empirical material collected via semi-structured interviews during 2012 on a sample of 24 families with children aged 2 to 12 . The constant comparative analysis (grounded theory method) includes attitudes and actions of parents of boys and girls (as a control group) in the process of family gender socialization, and enables interpretation of boys' gender socialization models on a continuum ranging from traditional to modern upbringing practices of parents. The research shows that parental practices in modern-day Serbia are still primarily traditional. Of the three distinct models of boys' gender socialization (traditional, transitional and participatory), the last two represent a step forward in the direction of the individualization of parenthood and more egalitarian gender socialization patterns influenced primarily by partner relationship dynamics. These dynamics are initiated by mothers' reflexiveness and the transformation of the concept of the "sacrificing motherhood". The dynamic of partner relationships thus shifts in the direction of "sacrificing fatherhood", that is, a father's renunciation of a part of the privileges he enjoyed before entering the responsibilities within the 
household. Interactions with the social environment (and perceived changes in it), as well as interactions with the family of origin are crucial elements in whose interrelation the upbringing practices of parents are built and within which gender socialization of boys takes place in the socio-cultural context of contemporary families in Serbia.

Keywords: gender socialization, upbringing practices, family, parenting, Serbia

Modèles de socialisation de genre chez les garçons des familles de la Serbie contemporaine

L'article traite le processus de socialisation familiale de genre chez les garçons dans le contexte socioculturel contemporain de Serbie, processus suivi à l'aide des pratiques éducatives des parents. L'analyse est basée sur le matériau empirique recueilli en 2012 auprès d'un échantillon de 24 familles ayant des enfants âgés de 2 à 12 ans. À partir d'une analyse comparative constante (méthode de construction de la théorie) des pratiques éducatives des parents - des pères et des mères, qui englobent leurs positions et comportements, dans le texte sont présentés et interprétés des modèles de socialisation de genre des garçons et se positionnent sur le continuum des pratiques extrêmement traditionnelles jusqu'aux pratiques éducatives extrêmement modernes des parents. Bien que les pratiques éducatives traditionnelles soient les plus représentées dans l'échantillon de cette recherche, dans l'analyse ont été relevés trois modèles de socialisation des garçons: traditionnel, transitoire i participatif. Les deux derniers modèles représentent un pas vers l'individualisation de la parentalité, et se développent avant tout sous l'influence de la dynamique des rapports entre partenaires, c'est-à-dire en raison du dépassement de la « maternité sacrificatrice » chez certaines femmes de l'échantillon en direction du « sacrifice» du père, c'est-à-dire du renoncement à une partie des privilèges dont il avait bénéficié avant de prendre en charge le soin et le bien-être des enfants.

Mots clés: socialisation de genre, pratiques éducatives, famille, parentalité, Serbie

Primljeno /Received: 21.07.2020

Prihvaćeno / Accepted: 20.11.2020 